\title{
VÁGÁSI TÜNDE
}

\section{MINITRAE ET NUMINI EIUS \\ Egy kelta istenség a vulgáris latin Aquincumban*}

\begin{abstract}
A tanulmány kiindulópontja az a Budapesten, a XII. kerület, Gyár utca 157. szám alatt előkerült, mészkőből készült oltár (1. ábra), amely a XX. század elején egy Balogh nevü magánszemély birtokában volt. ${ }^{1}$ 1899-ben Kuzsinszky Bálint írta le elsőként az oltárra vésett feliratot. ${ }^{2}$ Balogh halála után özvegye az I. kerület, Mozdony utca 17 . szám alá (ma Kiss János altábornagy utca) költözött, ahova az oltárt magával vitte, és beépíttette a ház falába. 1906-ban Kuzsinszky ellátogatott a házba, és ismét közzétette a feliratot az utolsó ismert képpel együtt. ${ }^{3} 1908$ után az oltárt elveszettként tartják számon. Az épület helyén ma a Budapesti Gazdasági SZC Budai Középiskolája (a Budapesti Közgazdaságtudományi Szakképző Központ Budai Gimnáziuma) található. Úgy tűnik, hogy az iskola építésekor, az egykori épület lebontása során a felirat örökre elveszett.
\end{abstract}

\section{Aurelius Florianus oltára Aquincumból ${ }^{4}$}

\author{
Minitrae \\ Aur(elius) $\circ$ Florian \\ us $\circ$ vet(eranus) $\circ$ ex $\circ b($ ene $) \circ f($ iciario $) \operatorname{co}(n) s($ ularis $)$ \\ pro salute $\{m\}$
}

* Jelen tanulmány az Innovációs és Technológiai Minisztérium ÚNKP-19-3 kódszámú Új Nemzeti Kiválóság Programjának szakmai támogatásával, valamint az NKFIH (OTKA) 108399 ny. sz. Császárkori latin feliratok számitógépes nyelvtörténeti adatbázisa: 3. szakasz című projektje keretében az MTA Lendület Számítógépes Latin Dialektológiai Kutatócsoportban készült. A tanulmány angol nyelvű változatát az Acta Classica Universitatis Scientiarum Debreceniensis közlésre elfogadta.

${ }^{1}$ CIL III 3474: „Ofen, Christinenstadt, FABRIKGASSE n. 157. In aedibus Balok.”

${ }^{2}$ Kuzsinszky B.: Aquincum római feliratai. BudRég 6 (1899) 109-150, kül. 132.

${ }^{3}$ Kuzsinszky B.: Magyarországon talált római kőemlékek a vidéki múzeumokban s egyéb helyeken. MKÉ 2 (1908) 77-79, 88 Nr. 5.

${ }^{4}$ CIL III 3474 = CIMRM-2, 1776 = TitAq I, 226 = CBI 378. Hosszúkás négyszögű tábla (oltárkő) mészkőből. LH: Budapest. ÖH: elveszett. Mérete: M: $66 \mathrm{~cm}$, Sz: $31 \mathrm{~cm}$; a felirat hornyolt keretben. Kuzsinszky: i. m. (2. jegyz.); Kuzsinszky: i. m. (3. jegyz.); R. Peter: Minitra. In: Roscher's Lex. Myth. II/2 (1894-1897) 2992; F. Heichelheim: Minitra. In: RE XV/2 (1932) 1848; Nagy T.: Vallási élet Aquincumban. Budapest Története I/2 (1942) 392 és 441, 71. jegyz.; Alföldy G.: Aquincum vallási éltének története. BudRég 20 (1963) 61 és 68, 134. jegyz.; M. Clauss: Cultures Mithrae. HABES 10 (1992) 179; Fehér B.: Pannonia latin nyelvtörténete. Budapest 2007. II. rész 1. 8. 1. 5, IV. rész 3. 2. 1.3 et 523 kül. 115; Á. Szabó: La religion et la Panthéon. In: Romains de Hongrie. Éd. A. Facsády - P. Zsidi. Lyon 2001. 62. 
mea $\{m\} \circ$ et om

nium $\circ$ meorum

Numini $\circ$ eius

$d<e>$ dicavi $\circ$ Sabino

II et Venusto co(n)s(ulibus)

3 kis O; 8 DIDICAVI pro dedicavi, kis $\mathrm{O}$

A feliratot Aurelius Florianus veterán állíttatta fel, aki mint beneficiarius consularis szolgált egy meg nem nevezett csapategységél. A felirat olvasata világos, az egyetlen kérdés, hogy ki lehetett a titokzatos Minitra. A consuldatálás alapján a felirat 240-ben készült. Aurelius Florianusnak egy másik feliratos oltára is előkerült Aquincumból, amelyet Iupiter Optimus Maximus tiszteletére állított. ${ }^{5}$ A személy neve és a felirat megfogalmazása egyaránt megegyezik a Minitra-feliratban szereplővel. Egyik esetben sem derül ki a katonai alakulat neve, amelyhez a beneficiarius consularis tartozott, a felirat előkerülési helye alapján azonban leginkább a legio II Adiutrix kerülhet szóba. Ugyanehhez a személyhez egy másik feliratot is köt a szakirodalom, amelyet Marcus Aurelius Cocceius Florianus a legio X Gemina primuspilusa állított Fortuna Conservatrix tiszteletére. ${ }^{6}$

\section{Minerva}

Az első kiadás óta a Minitra-oltár szövegét többször publikálták. Az istenség nevét számos kutató tanulmányozta, és különböző magyarázatokat javasoltak a titokzatos Minitra névre. ${ }^{7}$

Kuzsinszky Bálint mindkét közleményében a Minervae elírásaként értelmezte a Minitrae alakot. ${ }^{8}$ Minerva tiszteletének számos feliraton maradt nyoma Aquincumban, ${ }^{9}$ az istennő főként a capitoliumi triász tagjainak körében szerepel. Két melléknevét említik a feliratok: Victrix és Augusta. Az aquincumi legiotábor praetorium-szentélyében

${ }^{5}$ A Iupiternek állított oltár a Váradi utcában 1975-ben a Vörösvári út SZTK épülete mögött, vízműárok ásásából került elő (BTM Lsz. 74. 7. 7.) egy sírkert dombormü-töredékével együtt, amelyen (BTM Lsz. 75.7. 8.) egy álló Genius alak szerepel. A kövek eredeti előkerülési helyét a helyszínen már nem tudták megállapítani. TitAq I, 98 = CBI 377: I(ovi) O(ptimo) M(aximo) / Aur(elius) Flor/ianus b(ene)f(iciarius) / cons(ularis) pro / sal(ute) sua et / suorum / v(otum) s(olvit) l(ibens) m(erito).

${ }^{6}$ CIL III 14359, 26 = AEA 2001/02 + 60 = AEA 2005 +36 =AEA 2006 +10 = AEA 2010 +6: Fortunae / Conservatri(ci) / Cl(audius) M(arcus) Aur(elius) Cocce/ius Florianus / p(rimus) p(ilus) leg(ionis) X G(eminae) Sev(erianae) / cum suis / v(otum) s(olvit) l(ibens) l(aetus) [m(erito)]. szokatlan.

7 Theodor Mommsen a CIL-ben való közlés alkalmával csupán egy sickel jelölte, hogy az isten neve

${ }^{8}$ Kuzsinszky: i. m. (2. jegyz.) 144-145 Nr. 132 és Kuzsinszky: i. m. (3. jegyz.) 88 Nr. 5.

${ }^{9}$ Zsidi P.: Zur Verehrung der Minerva in Aquincum. BudRég 30 (1993) 185-209. 


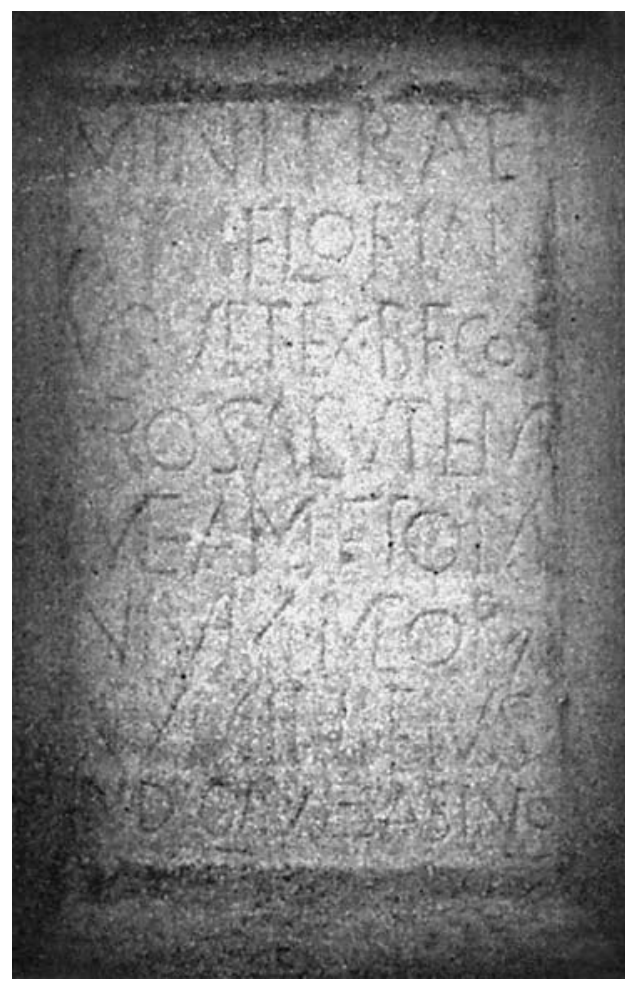

1. ábra.

maga a legatus állított oltárt a győzedelmes istennőnek, ${ }^{10}$ míg Marsnak és Minervának mint a harc tudományának és szellemiségének a legio II Adiutrix collegium armaturaruma állított feliratot. ${ }^{11}$ Nyelvi szempontból azonban igen nehezen indokolható a $\mathrm{Mi}$ nerva alak romlása Minitra formára. Ráadásul a Minerva név ritkán jelenik meg vulgáris formában. Mindössze néhány olyan példát ismerünk, ${ }^{12}$ ahol főleg az első szótag I / E hangváltozása figyelhető meg, ${ }^{13}$ de a példák száma az összes Minerva-feliratot tekintve elhanyagolható.

${ }^{10}$ legati: Lucius Septimius Flaccus (AE 1974, 512 = TitAq I, 195), Caius Valerius Pudens (CIL III 10438 = ILS 3131 = TitAq I, 225) és Caius Valerius Sabinianus (AE 1962, 119 = TitAq I, 189).

${ }^{11}$ CIL III 10435 = ILS 2363 = TitAq I, 214: Marti et Minerv(ae) // Aug(ustis) coll(egium) / armatura(rum) / leg(ionis) II Adi(utricis) / P(iae) F(idelis) / Antoninia/nae.

${ }^{12}$ MINNERV = Minerva vö. LLDB-24431. A továbbiakban a Császárkori latin feliratok számítógépes nyelvtörténeti adatbázisára (http://lldb.elte.hu/) adatbázisként vagy LLDB rövidítéssel, adatlapjaira pedig az LLDB-számmal hivatkozunk.

${ }^{13}$ LLDB-15135: MENERVAE; LLDB-5752: ME[NERV; LLDB-44998: MEN; LLDB-74685: MENERVA; CIL II 1950: MENERV; AE 2004, 451: MENER[VAE]; CIL XI 3081 = CIL I 365 = ILS $3124=$ ILLRP $238=$ ZPE-140-252 = AE 1998, 506: MENERVA. 


\section{Pannonia helyi istenei}

Egyes tudósok szerint Minitra kelta vagy helyi, pannoniai istennő lehetett, akinek a szóban forgó szöveg az egyetlen ismert felirata. A kelta azonosítást ugyanakkor minden alkalommal csakis Alföldy Géza 1963-as cikkére hivatkozva említik. ${ }^{14}$ Megfelelő érvek nélkül azonban nem fogadhatjuk el Minitra pannon vagy kelta eredetét, ehhez nem elegendő, hogy a névalakot egyszerüen keltának tekintjük. ${ }^{15}$ Csak néhány helyi istent ismerünk, akiknek jelenléte kizárólag Pannoniára jellemző, más tartományban viszont nem mutatható ki. Ezek közül kettő kultusza tekinthető teljes mértékben helyi, pannoniai eredetűnek, a Nutrices kultusza Poetovio környékén, ${ }^{16}$ valamint a Silvanus neve mögött rejtőző helyi istenek tisztelete. ${ }^{17}$

Ugyanakkor Pannonia területén az oltárokról és más kultuszhoz köthető feliratokról nem ismeretlenek a kelta istenek nevei. A kelta neveket gyakran a római istenek epitetonjaként adják meg, mint például Genius Ciniaemus ${ }^{18}$ és Silvanus Magla ${ }^{19}$ esetében. Bár a régészeti adatok azt sugallják, hogy sok helyi, kelta istent tiszteltek római név alatt (Diana, Silvanus, Hercules stb.), ${ }^{20}$ csak Vidasus és Thana gyógyító istenek ${ }^{21}$ - Aesculapius és Hygeia megfelelői - ismertek kelta névvel a feliratokról. ${ }^{22}$ A nevükön kívül azonban semmit sem tudunk ezekről az istenekről, csupán a római istenekkel való azonosítás révén lehet valamelyest fogalmunk arról, milyen funkciót töltöttek be.

A régészeti kutatások Aquincum területén több népesség keveredési pontját azonosították: a bennszülött illyr-pannon népcsoportok együtt éltek az eraviscus beván-

${ }^{14}$ Alföldy G.: Aquincum vallási életének története. BudRég 20 (1963) 51: „A bennszülöttek széles tömegeinél alig terjedt el a római kultuszforma, azaz a maradandó kőemlék állításával járó votum, és maguknak a római isteneknek a tisztelete. Ősi isteneik, mint Teutates, Sedatus, Ciniaemus, Minitra, stb. még a III. században is éltek, ha nem is változatlanul."

${ }^{15}$ W. Meid: Keltische Personennamen in Pannonien. Budapest 2005.

${ }^{16}$ Poetovio, lásd S. Kos: Nutrices: The Most Popular Goddesses at Poetovio. In: Zentralort und Tempelberg. Siedlungs- und Kulturentwicklung am Frauenberg bei Leignitz im Vergleich. Hg. M. Lehner - B. Schrettle. Graz 2016. 167-175.

${ }^{17}$ A Silvanus-kultuszhoz részletesen P. F. Dorcey: The Cult of Silvanus: A Study in Roman Folk Religion. Leiden 1992.

${ }^{18}$ CIL III 3617 = TRHR 246 = TitAq II, 941 = CBI 420. A kereskedők védelmező istenét, Genius Ciniaemust (vö. CIL III 5773) nevezi meg szintén egy beneficiarius oltára Iunóval együtt.

${ }^{19}$ CIL III 3963 = ILS 3576 = AIJ 548. Az epitheton azon kategóriába tartozik, amely Silvanus kifejezetten kulturális aspektusát határozza meg, mint erbarius, bellator vagy az interpretatio Romana által létrehozott formák: Mammula vagy Magla.

${ }^{20}$ Vö. Hercules Illyricus (AE 1948, 86), Silvanus és Silvanae (CIL III 10460, 13497), valamint Diana és Silvanus (CIL III 13368) közös említését.

${ }^{21}$ B. B. Plemić: Interpretatio Romana of the Forest Deities in the Central Balkan Area. ГCAA/JSAS 28 (2012) 47-61.

${ }^{22}$ CIL III 10819 = CIL III 14354, 23 = ILS 3910 = AIJ 518 = AE 1901, 216. Vidasius és Thana kétségkívül bennszülött, pannon-illyr istenek voltak, akiknek neve a romanizáció idején is megőrződött. Az illyr istenekhez A. Mayer: Die illyrischen Götter Vidasus und Thana. Glotta 31 (1951) 235-243. 
dorlókkal és más kelta törzsekkel. ${ }^{23}$ Egyes istenek törzsi istenségként határozhatóak meg. Ilyen például Iupiter Optimus Maximus Teutanus, ${ }^{24}$ aki az eraviscusok istene volt, neve eredeti formáját Bernardo Stempel Teutatisként rekonstruálja. Az isten kultuszkomplexuma Aquincum territoriumán, a Gellért-hegyen volt, és nemcsak Aquincummal, hanem Carnuntummal is kapcsolatban állt, ahol a pfaffenbergi szentélykörzetben Iupiter Optimus Maximus K(arnuntinus?) ${ }^{25}$ számára állítottak oltárokat. Egyes felvetések szerint a két isten valójában ugyanaz a kelta isten két helyi megtestesülése volt, akit a két pannoniai provincia fővárosában tiszteltek.

\section{Mithras kultusza Aquincumban}

A XX. század elején született nagy Mithras-corpusok mindegyike közli a feliratot mint a Mithras-kultusz szöveges emlékét. Az első nagyobb terjedelmű gyüjtemény Franz Cumont $^{26}$ munkája, aki a feliratot mindenféle kommentár nélkül közli. Ezt az átírást vette át Marten Joseph Vermaseren az 1960-as években kiadott monumentális gyűjteményébe, ugyancsak kommentár nélkül hagyva az első sorba vésett Minitrae-t. ${ }^{27} 1992$-ben Manfred Clauss szintén kiadta a feliratot a Mithras-kultuszról szóló munkájában. ${ }^{28}$ Clauss már annyit megjegyez, hogy Minitra alatt minden bizonnyal Mithrast kell érteni. E. Diehl a Vulgarlateinische Inschriftenben szintén úgy fogalmaz, ${ }^{29}$ hogy a Minitrae a Mithrae egyik formája. ${ }^{30}$

A legyőzhetetlen napisten, Mithras kultusza a II. és III. században igen elterjedt volt Pannoniában. A számos felirat és több szentély tanúsága alapján ez volt Aquincum területén az egyik legnépszerúbb kultusz. Aquincumban mai ismereteink szerint több

${ }^{23}$ Topál J: Ethnic Components in the Cemeteries along the Limes of Pannonia Inferior. In: Roman Frontier Studies 1995. Proceedings of the XVIth International Congress of Roman Frontier Studies. Eds. W. Groenman-van Waateringe - B. L. van Beck - W. J. H. Willems - S. L. Wynia. Oxford 1997. 537-545.

${ }^{24}$ Pócz K.: Iuppiter Optimus Maximus Teutanus Aquincumban. In: Pannoniai kutatások. A Soproni Sándor emlékkonferencia előadásai. Szerk. Gaál A. Szekszárd 1999. 201-223; Hampel J.: Az eraviscus nép és emlékei. BudRég 4 (1892) 31-73.

${ }^{25}$ I. Piso: Das Heiligtum des Jupiter Optimus Maximus auf dem Pfaffenberg/Carnuntum: 1. Die Inschriften. Wien 2003 és W. Jobst: Jupiter Kapitolinus oder Jupiter Karnuntinus. In: Akten des XI. Internationalen Limeskongresses. Hg. J. Fitz. Budapest 1977. 155-164, amely szerint a K rövidítés Karnuntinusként való feloldása kétséges.

${ }^{26}$ Textes et monuments figurés relatifs aux Mystères de Mithra. Éd. F. Cumont. Bruxelles 1899. Nr. 326.

${ }^{27}$ CIMRM 1776.

${ }^{28}$ Clauss: i. m. (3. jegyz.) 9.

${ }^{29}$ E. Diehl: Vulgarlateinische Inschriften. Kleine Texte für Vorlesungen und Übungen 62 (1910) 15. Nr. 132.

${ }^{30}$ Mások is a Mithras-kultusz emlékeként hivatkoznak a feliratra, lásd C. L. Patsch: Archäologisch-epigraphische Untersuchungen zur Geschichte der röm. Provinz Dalmatien I-IV. Wien 1900. 93: „ganz unerhört ist die Verstümmelung des Namens des Mithras durch den Steinmetz nicht, man findet auch Methrae, Mythirae, Minitrae, Mitrae, Mythrae, Mitrhrae, Mitrhe u. s. w." 
Mithras-szentély (mithraea) működött egy időben mind a civil, mind a katonaváros területén, melyek közül a legelsőt még a Kr. u. 160-as évek elején építették. ${ }^{31}$ Mithras neve tizenhét feliraton, alakja legalább hat domborművön egyedül, valamint további tizenegy domborművön két társával, Cautesszel és Cautopatesszel együtt látható, ezek a kultuszemlékek Aquincum különböző részein kerültek elő. A mithraikus közösségek általában 20-50 emberből álltak, akik szoros kapcsolatban voltak egymással. A szentélyek méretéből adódóan nem következtethetünk nagyobb létszámú közösségekre, mivel a kultikus események valamennyi hívő jelenlétében történtek. A közösség iránti elkötelezettséget valószínűleg titokban tartották. Ez lehet az oka annak, hogy a szentélyeket vagy a városon belüli magánházakhoz csatolták, vagy a városon kívüli ingatlanok esetében kerítéssel vették körbe, elrejtve a kívülállók szemétől.

Aquincumban tizenhat feliraton különféle formában jelenik meg az isten neve. Csak egyetlen esetben vésették a Mithrae alakot teljesen és helyesen a feliratra. A legtöbbször a megszokott formában rövidítették: $M(i t h r a e)$. Három esetben teljesen kiírva, de hibás alakban szerepel az isten neve: Mit(h)rae, ${ }^{32} M y t h r a e^{33}$ és Mitrhae, ${ }^{34}$ ezek közül két felirat a tribunus laticlaviusok mithraeumából származik. ${ }^{35}$

\section{Numini Mithrae}

A numini eius formula szintén arra enged következtetni, hogy az isten Mithrasszal azonos. Leggyakrabban a császárkultusszal összefüggésben említik az oltárok egy istennek vagy a császárnak a numenjét, ezzel utalva isteni voltukra. ${ }^{36} \mathrm{~A}$ formulát gyakran Mithrashoz is társítják, ${ }^{37}$ ahol a numen egyenértékủ a Deus mint isteni erővel. A numini

${ }^{31}$ Zsidi P.: Nagy Tibor és az aquincumi Mithras-kutatás. BudRég 44 (2011) 20-31.

${ }^{32}$ CIL III 3480 = CIMRM-2, 1774 = TitAq I, 260; AE 1910, 127 = CIMRM-2, 01781 = TitAq I, 261 és RIU 1355 = EpPann-3, p 26 = AE 2004, +1133.

${ }^{33}$ CIL III 3481 = ILS $4260=$ CIMRM-2, 1790 = TitAq I, $256=$ GeA 349.

${ }^{34}$ AE 1990, 818 = TitAq I, 252.

${ }^{35} \mathrm{Az}$ Aquincum területén található szentélyek között az V. Mithraeum különleges helyet foglal el. Jelentősége abban rejlik, hogy a katonai táboron belül a tribunus laticlaviusok házának egyik helyiségében volt. Jelenlegi ismereteink szerint ez az egyetlen olyan szentély, amely egy katonai tábor falai között található.

${ }^{36}$ D. Fishwick: Numina Augustorum. CQ 20 (1970) 191-197.

${ }^{37}$ AE 1991, 1301 (Pannonia superior, Poetovio); CIL III 968 = CIL III $7729=$ CIL III $7730=$ ILS 4241 = FMFS 252 = IDR III/2, 306 = CIMRM-2, 2007 = CIMRM-2, $2010=$ Sicoe-2014, $188=$ Sicoe-2014, 189 (Dacia, Acidava); CIL III $1549=$ IDR III/1, $145=$ CIMRM-2, $2153=$ CERom-3, 225b = AE 1983, 799b = AE 2008, +1157 = Sicoe-2014, 203 (Dacia, Tibiscum); CIL V 8997 = Pais 892 = EaNovara 26 = CIMRM-1, 704 = MLNovara p 131 (Transpadana, Novaria); CIL VI 724 = ILS 4204 = CIMRM-1, 526 (Roma); CIL VI 747 = CIMRM-1, 553 (Roma); CIL XI 5736 = ILS 4207 = CIMRM-1, 687 = CIMRM-2, p 33 = AE 2006, +243 (Umbria, Sentinum); CIL XIV 3567 = EE-09, p 469 = InscrIt-4-1, 67 = ILS 4237 = CIMRM-1, 214 = Louvre 30 (Samnium, Tibur); AE 1965, 32 = IDR-3-4, 46 = IDR-3-5-1, 56 = CIGDac 15 (Dacia Apulum); AE 1940, $81=$ ISDoli 15 = CIMRM-1, 470 = CCID 370 (Rome); CIMRM-1, 754 = InscrIt-10-2, 216 (Venetia, Parentium). 


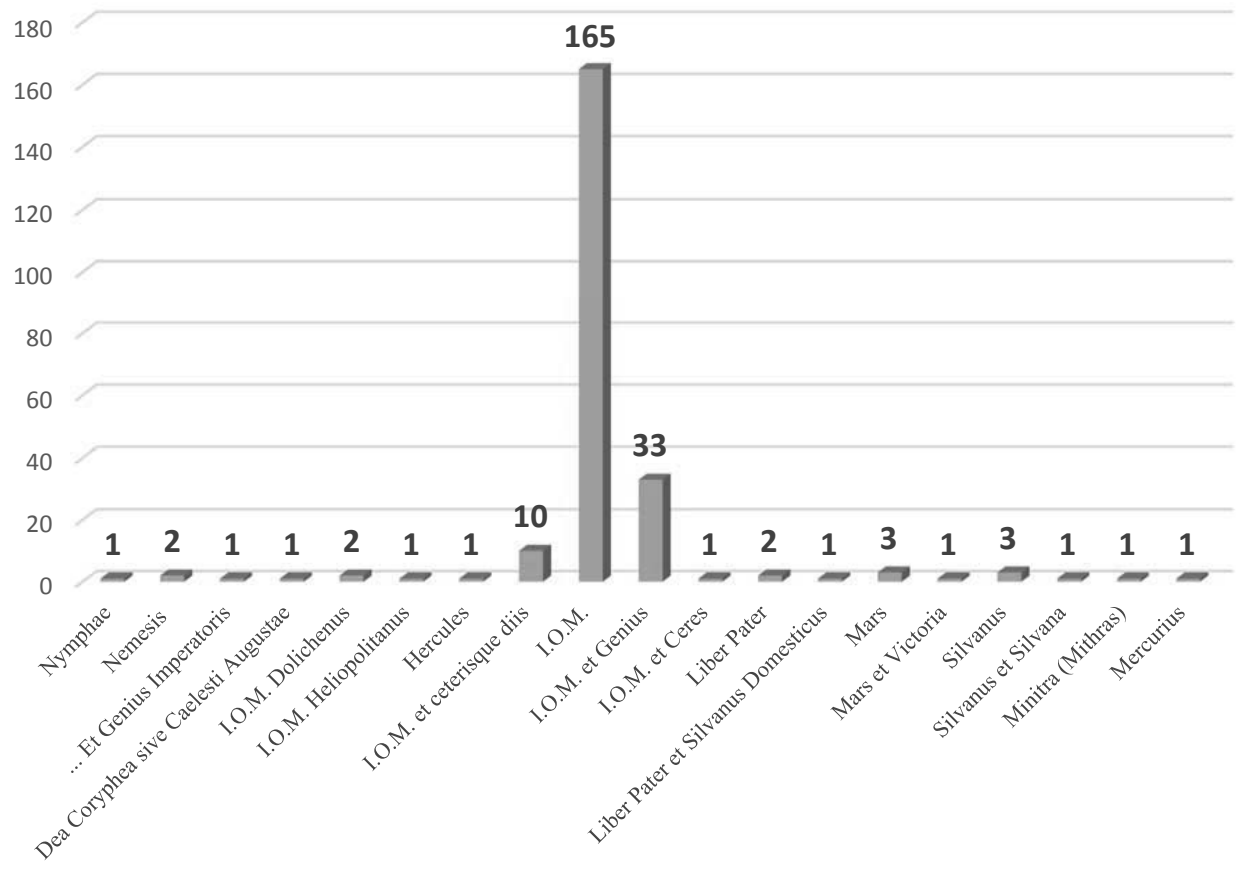

2. ábra. A beneficiarius consularisok által tisztelt istenek Pannoniában

Mithrae kifejezés ismert a Santa Prisca mithraeumból ${ }^{38}$ vagy a Pannonia superiorhoz tartozó poetoviói mithraeumból is. ${ }^{39}$

\section{A beneficiarius consularisok vallási feliratai Pannoniában}

A Kr. u. II. század elejétől kezdődően az adminisztrációs központok közelében, a tartományok fő útjai mentén beneficiarius állomásokat hoztak létre. A legtöbb beneficiarius állomás Pannoniában a Borostyánút mentén, valamint a Pannonia déli részén lévő út mentén volt. Az átlagosan egy év szolgálatot teljesítő személyek különböző funkciókat töltöttek be: beneficiarius consularis, beneficiarius laticlavi, beneficiarius legati legionis, beneficiarius praefecti, beneficiarius procuratoris attól függően, hogy kinek a szolgálatában álltak. A legkorábbi felirat, amit Pannoniában egy beneficiarius állíttatott, egy Mursában 164-ben felállításra került oltár. ${ }^{40}$ A beneficiariusok a legtöbb feliratot a római főistennek, Iupiter Optimus Maximusnak (2. ábra) ajánlották. A Pannoniában

${ }^{38}$ CIMRM-1, 497 = SPrisca p 340e = AE 1941, 78 = AE 1946, +82: Deo Soli Invicto Mithr(a)e / quod saepe Numini eius / ex audito gratias e[t vota] / [reddere moniti sunt].

${ }^{39}$ AE 1991, 1301: D(eo) S(oli) I(nvicto) M(ithrae) / Num(ini) Sanct(o) / et Praest(antissimo) / L() Van$\operatorname{der}($ ) / v(otum) s(olvit) l(ibens) m(erito) / [...] Kal(endas) Novem(bres) / Severo et Quint(iano) / p(atre?) p(rosedente?) SII[...

${ }^{40} \mathrm{AE} 1973,448=\mathrm{CBI} 413$. 
a beneficiarius consularisok által elhelyezett fogadalmi emlékek valamivel több mint 70\%-át Iupiter Optimus Maximusnak szentelték. Sirmiumban több mint nyolcvan oltárt, valamint tizenkét bronz- és kőszoborot fedeztek fel az egyik beneficiarius állomás szentélyében. ${ }^{41}$ A feliratok nagy többségét egyedül Iupiternek dedikálták, de időnként a Geniusokkal vagy a többi istennel és istennővel együtt (I.O.M. et ceterisque diis deabusque) szerepel ezeken a feliratokon. Ha ehhez hozzáadjuk azokat a feliratokat, amelyekben a legfőbb isten mellé Iuno, Ceres, a Geniusok vagy más római istenek társulnak, akkor 89\%-os arányt kapunk. Az eredmény sokkal magasabb a birodalom egészéhez viszonyítva, de a római istenek aránya még a szomszédos Dacia 60\%-os arányához képest is kimagasló. ${ }^{42}$

\section{A MINITRA alak létrejötte}

A MINITRA név pontosabb megértése és az értelmezésével kapcsolatos álláspont kialakítása érdekében meg kell vizsgálnunk az oltár szövegét. Figyelembe véve az egyetlen, rossz minőségű fényképet, úgy tűnik, hogy az első két betű $\mathrm{ME}$, így az első sorban Menitrae szerepel. A felirat készítője már az elején rosszul kezdte el felvésni a szöveg első szótagát, és ez okozhatta az isten nevében a további problémákat is. A CIL III 3474 felirat új olvasata tehát a következő:
1 MENITRAE
2 AVR FLORIAN
3 VS VET EX BF COS
4 PRO SALVTEM
5 MEAM ET OM
6 NIVM MEORVM
7 NVMINI EIVS
8 DIDICAVI SABINO
9 II ET VENVSTO COS

Az eddigiek fényében rátérhetünk a hangtani alapú magyarázatra. Ha elfogadjuk a $M e-$ nitrae olvasatot, akkor az első hiba a dittográfia, az első szótag megkettőzése, amely azért jött létre, mert a vésnök tévesen két betűt (vagy esetünkben két szótagot) írt egy helyett a másolás során. Az ilyen típusú hiba nagyon gyakran fordul elő a latin feliratokon, így Aquincumban is. ${ }^{43}$

\footnotetext{
${ }^{41}$ M. Jeremic - P. Milosevic - M. Mirkovic - P. Popovic: Le sanctuaire des beneficiarii de Sirmium, présenté par N. Duval. In: Religio Deorum. Ed. M. Mayer. Tarragona 1992. 145-149.

${ }^{42}$ M. Popescu: La religion dans l'armée romaine de Dacie. Bucarest 2004. 283.

${ }^{43}$ A TitAq I, 516 feliraton: Fortunatata két TA ligatúrával, a TitAq I, 589-en merentisisima a merentissima helyett.
} 
Az első szótagban lévő E I magánhangzók feliratos tévesztései más mithraikus feliratokon is megjelennek, ${ }^{44}$ egy dalmatiai kultuszképen Metherae ${ }^{45}$ egy másik dalmatiai feliraton Meter[ae] formában, ${ }^{46}$ egy elveszett római feliratra pedig Methrae volt felvésve. ${ }^{47} \mathrm{~A} \mathrm{Kr}$. u. II. század végére az aquincumi magánhangzó-változásoknak is meghatározó folyamatává válik az E / I fúziója, mindenekelőtt a hangsúlytalan /e/ I-ként írása - illeszkedve az átlagos birodalmi mintához. Ezzel szemben a hangsúlyos hosszú /i/ és /e/ Aquincumban és Salonában nagyobb arányban fordul elő téves írásmóddal, mint máshol a birodalomban. ${ }^{48}$

A fent említett E / I változás mellett az M / N kontamináció is megjelenik. Ezt a jelenséget a római Pannonia területéről származó számos felirat tanúsítja. Van azonban más magyarázat az $\mathrm{N}$ jelenlétére, szintén Aquincumból. A vésnök vagy másoló esetleg egy intervokális $\mathrm{N}$ betűt illesztett be a Methrae szóba. Eddig egy hasonló alak bukkant fel a feliratos anyagban, az ugyaninnen, Aquincumból ismert Cnaeus Pompeius Felix sírfeliratán születési helyként Ionudrom szerepel. ${ }^{49}$ A település azonosítása meglehetősen nehéz, Lassányi szerint az első két betű a dio- előtagot jelöli, és van egy közbeillesztett $\mathrm{N}$, tehát a hely a galliai Diodurum (ma Jouars-Pontchartain) vagy a Divodurum Mediomatricorum (Metz) lehetett. Meg kell azonban jegyeznünk, hogy erre az intervokális N-re csupán ez a feltételezett adatunk van, a vizsgálat eredményei bizonyos mértékig ideiglenesnek tekintendők, az Adatbázisban az aquincumi feliratos anyag feldolgozása még nem teljes, a jelenlegi szakaszban pedig nincs elegendő példánk ahhoz, hogy ezt a közbeillesztést pannoniai jellegzetességnek tekinthessük.

A Th / T tévesztése a hangtani változásokból adódó helyesírási hibák közé (errores quasi orthographici) tartozik. Már az ólatin korszaktól előfordul a feliratos forrásokban a hehezetes mássalhangzók egyszerüsítése, így a PH / P-vé, a TH / T-vé, a CH / C-vé válása. A legtöbb ilyen változás a személynevekben fordulhat elő, illetve a leggyakoribb a latin feliratokba átvett görög szavak esetében. Ez az ortográfiai pontatlanság annyira régóta ismert és széles körben elterjedt, hogy nem nyújt pontos adatot a latin nyelv Aquincum területén történő használatáról. ${ }^{50}$

Mindezek az eredmények igazolják feltevésünket, miszerint a feliraton Mithras nevét írták el, emellett azonban a felirat más nyelvi hibákat is tartalmaz. Az utolsó előtti

\footnotetext{
${ }^{44}$ Adamik B.: A számítógépes latin dialektológia régi-új útjain: a vulgáris latin magánhangzó-fúziók, a szinkópa és a hangsúly korrelációja. In: Nyelvelmélet és dialektológia. Szerk. É. Kiss K. - Hegedüs A. - Pintér L. Budapest 2015. 11-24.

${ }^{45}$ LLDB-221: CIMRM-2, 1892 = AEHercegovine 28 = ILJug-1, 112 = AE 1906, 184.

${ }^{46}$ LLDB-28122: CIL III 14617 = CIMRM-2, 1896 = AEHercegovine 9.

${ }^{47}$ LLDB-37068: CIL VI 511 = CLE $1529=$ CCCA-3, $243=$ CIMRM-1, $522=$ CMRDM-2, p $177=$ CMRDM-3, p 119.

${ }^{48}$ Gonda A.: Az Aquincum-Aquileia-Salona háromszög: latin nyelv a római birodalom Alpok-Duna-Adria régiójában. In: Scientia et ethica. Hereditas graeco-latinitatis 4. Szerk. Tóth O. Debrecen 2017. 161-195.

${ }^{49}$ Lassányi G.: Bevándorlók Aquincumban. Óbudai Anziksz 4 (2018) 95-97.

${ }^{50}$ Gonda: i. m. (48. jegyz.).
} 
sorban didicavi szerepel dedicavi helyett. ${ }^{51}$ Pannonia epigrafikus anyagában nagyon sok példa akad az igealakok ingadozására. A Kr. u. III. század második felére elég elterjedtté vált a de- / di- praeverbiumok egybeesése nemcsak Pannoniában, hanem az egész birodalomban.

A felirat szövegének egy másik vulgáris latin jellegzetessége a pro salutem meam kifejezés. ${ }^{52}$ A pro nagyon sok ablativusos alakja mellett a vizsgált feliraton kívül csupán háromszor vonz accusativust a pannoniai feliratos anyagban. Mindegyik ugyanarra a korszakra, a Severusok idejére keltezhető. Az accusativus és ablativus esetek egybeolvadása mellett más esetkeveredés is gyakori volt a vulgáris latin nyelvben, ezek következményei lettek a vulgáris latin esetrendszer területileg eltérő változatai, amelyekben a klasszikus ötesetes ragozásból két- vagy háromesetes névszóragozási rendszer jött létre. A cum, ob és pro prepozíciókat illetően megfigyelhetjük ennek a névszóragozási egyszerűsödésnek a folyamatát, így az ablativus és az accusativus esetek keverését. További négy feliraton szerepel Pannoniában pro salute sua helyett pro salutem suam. ${ }^{53}$ Ezenkívül legalább harminc hasonló felirat ismert más római tartományokban. Teljes írnoki bizonytalanság tükröződik tehát az egész oltár megszövegezésében.

A mithraikus emlékeket összegyűjtő monumentális munka alapján, amelyet Vermaseren 1960-ban készített, valamint az Epigraphische Datenbank Causs-Slaby adatainak felhasználásával elmondható, hogy Mithras nevének írása nem egységes. Az isten nevét a görög nyelvből vették át, ahol Mï poc formában írták, latinul Mithras átírással, és az első declinatio szerint ragozták. Mithrast invokáló feliratot több mint ötszázhuszat ismerünk a Római Birodalom területéről, a legtöbb esetben $D($ eo $) S($ oli) I(nvicto) M(ithrae) formában rövidítve - azonban a kultuszhoz tartozó feliratok száma ennél jóval nagyobb. A votív feliratok többsége az említett általános rövidítést tartalmazza, ezenkívül gyakori még a Mi(thras), Mit(hras) rövidítés is, ezektől eltérően azonban számos variánsa szerepel a feliratokon: Mithrae, Methrae, Mitre, Mitrai, Minitrae, Mitrae, Mythrae, Metras, Midre, Mytrae, Mythrae.

A fenti variánsok késztettek bennünket arra, hogy az LLDB adatbázisában rögzített összes Mithras-előfordulást áttekintsük (3. ábra). Az elemzésbe bevontuk a birodalom teljes latin nyelvű részét, így több mint negyven provincia mithraikus feliratait vizsgáltuk az adatbázis eddig feldolgozott anyagán keresztül. A vizsgálatból kizártuk azokat az adatlapokat, amelyek nem hangtaniak, hanem morfoszintaktikaiak voltak. Az LLDB adatbázis adatai alapján látható, ${ }^{54}$ hogy Mithras névváltozásában a korábban említett Th / T, vagyis a beszélt nyelv mássalhangzóinak egyszerűsítése figyelhető meg a legtöbb alkalommal. Külön csoportot alkotnak a nem nyelvi, hanem írástechnikai hibák, például betűváltás vagy dittográfia stb. A magánhangzóhibákat (vocalismus) illetően viszony-

\footnotetext{
${ }^{51}$ LLDB-14902.

${ }^{52}$ LLDB-14901.

${ }^{53}$ E. Beu-Dachin: The Latin Language in the Inscriptions of Roman Dacia. Cluj-Napoca 2014.

${ }^{54}$ Az adatbázis (http://lldb.elte.hu/) adatait a 2019.11.16-i állapot szerint használtuk fel, és a diagramokat is az adatbázis diagram-ábrázoló moduljával generáltuk.
} 


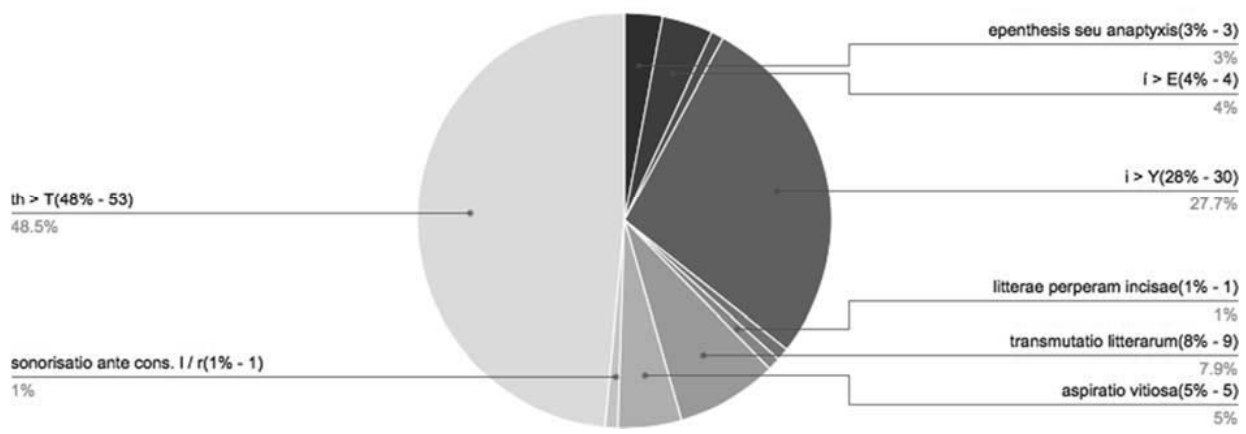

3. ábra.

lag nagyszámú adattal dolgozhattunk, főleg az első szótagra korlátozottan, különösen az I és Y közötti ingadozás (28\%) emelhető ki. ${ }^{55} \mathrm{Az}$ I helyetti hiperkorrekt Y használata Mithras nevében Pannoniában csupán egyetlen feliraton szerepel. A név görög eredete magyarázhatja ezt a hiperkorrekt Y-t. Epenthesis, vagyis bontóhangzó beillesztése (esetünkben E vagy I) csak néhány esetben jelent meg a TH és az R között. ${ }^{56} \mathrm{~A}$ hoszszú, hangsúlytalan i / E-ként való ejtése valószínüleg a bontóhangzó beillesztésével állt összefüggésben. A vázolt folyamatok (dittografia, az I / E és TH / T közötti ingadozás) arányosak az adott területen tapasztalható más szavakban előforduló tévesztésekkel, így nem beszélhetünk egyéni vonásról.

\section{Összefoglalás}

Összefoglalva az eddigieket megállapíthatjuk, hogy más kultuszokkal szemben Mithras kultuszának szociolingvisztikai vizsgálatánál nagyon nehéz helyzetbe kerülünk, mivel szinte semmit sem tudunk annak történetéről és tanításairól.$^{57}$ Csak a régészeti leletek és a kultusztagok feliratai szolgálhatnak referenciaként a hívők társadalmi és nyelvi hátteréhez. A felirat állítójának társadalmi státuszáról, kulturális hátteréről, származásáról sokszor a leghitelesebb információt éppen nyelvhasználatának sajátosságai árulják el.

${ }^{55} \mathrm{Az}$ LLDB adatbázisban harminc példa található erre a vokális változásra, amelynek oka a görög befolyás is lehet: LLDB-19641; LLDB-19514; LLDB-15510; LLDB-538; LLDB-16552; LLDB-15185; LLDB-9160; LLDB-5923; LLDB-5922; LLDB-5921; LLDB-5918; LLDB-70116; LLDB-70112; LLDB-65675; LLDB-65598; LLDB-65593; LLDB-50185; LLDB-37008; LLDB-36811; LLDB-28139; LLDB-28138; LLDB-28134; LLDB-28131; LLDB-28118; LLDB-28112; LLDB-28060; LLDB-28051; LLDB-27154; LLDB-27155; LLDB-26996. lum).

${ }^{56}$ Mythirae (LLDB-5902; IDR III/5 272 = CIL III 1112 = CIMRM-2, 1945 = Sicoe-2014, 26; Apu-

${ }^{57}$ László L. - Nagy L. - Szabó Á.: Mithras és misztériumai I-II. Budapest 2005. 
Úgy tủnik, hogy a feliratokat befolyásolta a beszélt nyelv, és a mithraikus feliratokon talált hibák a hívők beszélt nyelvi sajátosságait tükrözik. ${ }^{58} \mathrm{~A}$ hivatalos kultuszoktól eltérően a Kr. u. II. és III. században megjelenő új vallási irányzatok gyakran több vulgarizmust mutatnak az istenek számára felállított kultikus feliratokon. Az istenek nevének ilyen vulgáris formában történő írása kevésbé szigorú kapcsolatra utal a hívő és isten között, mint ahogyan ez korábban lehetséges volt a római vallásban, ahol alapvető a formalitások betartása. Nem zárhatjuk ki teljes bizonyossággal, hogy helyi kelta vagy pre-kelta isten volt Minitra (vagy Menitra), akinek tisztelete a Kr. u. III. századi Aquincumban újjáéledt. Ennek ellenére a fentebb vázolt érvek mind azt sugallják, hogy ez esetben is Mithras sokféle variációban szereplő névváltozatáról van szó.

\author{
VÁGÁSI TÜNDE \\ ELTE BTK Ókortörténeti doktori program \\ vagasitunde6@gmail.com
}

A cikk a Creative Commons Attribution 4.0 International License (https://creativecommons.org/ licenses/by/4.0) feltételei szerint publikált Open Access közlemény, melynek szellemében a cikk bármilyen médiumban szabadon felhasználható, megosztható és újraközölhető, feltéve, hogy az eredeti szerző és a közlés helye, illetve a CC License linkje és az esetlegesen végrehajtott módosítások feltüntetésre kerülnek. (SID_1)

${ }^{58}$ Mithras nem az egyetlen. A Kr. u. II. és III. században egyre több vulgáris jelenséggel találkozunk a vallási feliratokon szereplő istenek nevében. Iupiter Dolichenus nevét többször is Dulcenusként írják, ez a forma egyáltalán nem egyedülálló Pannoniában. Vágási T: Jupiter Dulcenus. Vallástudományi Szemle 4 (2017) 95-115. 